\title{
Tracing the Changes in Reading Scores and Learning Style Preferences through Reading Strategy Training
}

\author{
Mehmet Abi a* (iD), Şevki Kömür ${ }^{b \dagger}$ \\ ${ }^{a}$ Muğla Sitkı Koçman University, School of Foreign Languages, Kötekli, Muğla, 48000, Türkiye \\ ${ }^{b}$ Muğla Sitkı Koçman University, Faculty of Education, Department of English Language Teaching, Kötekli, Muğla, \\ 48000, Türkiye
}

Received 2 April 2018 | Received in revised form 5 September 2018 | Accepted 10 September 2018

\begin{abstract}
APA Citation:
Abi, M., \& Kömür, Ş. (2018). Tracing the changes in reading scores and learning style preferences through reading strategy training. Eurasian Journal of Applied Linguistics, 4(2), 213-237. doi: 10.32601/ejal.464121
\end{abstract}

\begin{abstract}
This study aimed at investigating possible effects of reading strategy instruction on students' language learning style preferences and their reading proficiency levels. A total of 6211 th grade students from three different classes (one treatment and two control groups) of a Turkish high school took part in this experimental study which lasted for eight weeks. In the scope of this study, Learning Style Survey (LSS) developed by Cohen, Oxford and Chi (2005), Survey of Reading Strategies (SORS) by Mokhtari and Sheorey (2002) and Key English Test (KET) were applied to the target groups both before and after reading strategy instruction. The data obtained from these three instruments were compared. Results demonstrated that reading strategy training may have an effect on students' language learning style preferences, possibly leading students to be more synthesizing and field dependent.
\end{abstract}

(C) 2018 EJAL \& the Authors. Published by Eurasian Journal of Applied Linguistics (EJAL). This is an open-access article distributed under the terms and conditions of the Creative Commons Attribution license (CC BY-NC-ND) (http://creativecommons.org/licenses/by-nc-nd/4.0/).

Keywords: Reading strategies; language learning styles; strategy based instruction; reading strategy training; metacognitive strategy training

\section{Introduction}

Throughout history, people have tried to teach and learn languages through various methods. In this arduous process of language teaching and learning, they used many methods and approaches influenced by the different dominant language theories of their time. As Williams and Burden (2000) point out theories such as folk view, behaviorist, cognitive, constructivist, social-interactional and humanistic all have yielded versatile and varying methods or approaches to reaching the ideal way of teaching a language. However, through the end of the 20th century, it has been

\footnotetext{
* Corresponding author. Tel.: +90-505-821-5282

E-mail address: mehmetabi@mu.edu.tr

† coal@mu.edu.tr
} 
understood that no individual method or approach is alone enough to provide the desired success and this has led the emergence of postmethod condition (Kumaravadivelu, 2006).

Having figured out that success is largely unrelated to the methods or approaches used, researchers shifted their focus to individual differences. As Macaro (2010) states, attention was shifted to why some learners do better than others. Actually, the cornerstone of this shift was Rubin's (1975) study in which she identified some characteristics of good language learners. Soon, it was found that there are many variables affecting the success of language classes. Many researchers, among whom are Cohen (2010), Williams and Burden (2000), Dörnyei (2010), Brown (2001, 2007), Grifiths (2008), Nyikos (2008), Green and Oxford (1995) and Wong and Nunan (2011), have tried to shed light on this issue by investigating the variables affecting language learners' success. These researchers and many others identified several variables such as age, gender, nationality, students' backgrounds, language aptitude, learning style preferences and language learning strategy use.

Although studies on these and other variables dominated the field for some time and researchers tried to develop better methodologies to improve students' achievement levels, later it was found that, as Cotteral (2008) states, there is no such a thing as an ideal teaching method. Instead, he suggested that more attention should be paid to individual learners. Hence, individual students have gained importance. For quite a long time researchers have been investigating individual students in terms of the differences they bring into the classroom environment two of which are their preferred language learning styles and language learning strategy uses.

To this end, this study examines high school students reading strategy uses, their language learning style preferences and proficiency levels. In addition, it is also aimed to reveal the relationship between reading strategy instruction and students' preferred language learning styles, reading strategy use and their proficiency levels.

\section{Review of literature}

\subsection{Learning styles}

There is not a single class consisting of students who enjoy learning in the same way. Each individual brings his/her own preferences to the learning environment and these preferences are reflected in their learning style preferences. Brown (2007), Cohen (2003), Kinsella (1995), Oxford (2001), Reid (1998), Oxford (2003) and Hedge (2008) have all tried to define what "learning style" means in their studies. Oxford (2003) defines learning style as "an overall pattern that provides broad direction to learning and makes the same instructional method beloved by some students and hated by other [students]" (p. 273) and Cohen (2003) as "general approaches to language learning" (p. 
279). In short it can be said that learning styles are general traits that characterize our way of learning.

In literature, there are several positive views about the role of being aware of learners' language learning style preferences (LLSP hereafter). According to Erhmann, Leaver and Oxford (2003), the more the teachers can tune their instruction to the learners' LLSP, the more likely they can maximize the efficiency of their classes. Nel (2008) also argues that "successful learners seem to be able to adopt learning styles particular to the task or situation" (p. 57). So, if learners' learning styles can be identified and if learners are aware of their own learning styles, then it is possible that they can adopt new learning styles and as a result more efficient teaching and learning situations can be achieved. So, many instruments have been presented so far in order to identify learners' LLSP. Some of the instruments which have been proven to be highly reliable and valid are Kolb's (1976) Learning Style Inventory (LSI), Reid's (1987) The Perceptual Learning Style Preference Questionnaire (PLSPQ), Oxford's (1993) The Style Analysis Survey (SAS), Erhmann and Leaver's (2003) The Erhmann and Leaver Learning Style Questionnaire, and Cohen, Oxford and Chi's (2005) Learning Style Survey (LSS) which was adapted from Oxford (1995) and Erhmann \& Leaver (2003).

In the questionnaire developed by Cohen, Oxford and Chi (2005), learning styles have been divided into eleven categories aimed at providing information about learners' sensory/perceptual learning styles, psychological type (personality), and cognitive learning styles. The characteristics of these three categories and the support that teachers can provide are well documented and summarized in Cohen and Weaver's (2006) book, Styles and Strategies-Based Instruction: A Teacher's Guide. In all these instruments, style preferences were given in dichotomies such as field-independent vs. field-dependent, leveler vs. sharpener, impulsive vs. reflective and so on. However, Nel (2008) and Oxford (2003) state that using dichotomies does not mean that a learner completely has one style or its bipolar opposite. Instead, they operate somewhere between them. For example, a learner who is dominantly visual may also have an auditory style to a degree. In this respect, some researchers such as Cohen and Weaver (2006) point out that students' LLSP can be changed - which lays the foundation for styles-based instruction. From a similar point of view, Brown (2007) argues that accepting styles as stable traits are questionable and he points out that different contexts will evoke different styles in the same individual (p.120). An individual may be more extroverted when learning a language but may be more introverted in mathematics.

So, it would be wrong to assume that one style is superior to another. According to Wong and Nunan (2011), the pedagogy needs to be style-neutral and learners should be encouraged to stretch their styles. On the other hand, they say that learners stretch their styles if the teacher stretches. Another issue in this respect is style matching. According to Cohen (2010) a match between teachers' teaching and the way learners' 
learn can maximize the learning process. Trying to establish a match, however, between the teaching and learning styles seems unrealizable.

\subsection{Language learning strategies}

Another important variable that has a significant effect on the success of the language learning process is language learning strategies, which has a close relationship to learners' LLSP and which has attracted the attention of many researchers. Because, as Cohen (2007) states, there is agreement that language learning and language use both in general and in specific tasks are improved with strategies. That is, for successful language learning experiences, appropriate use of related strategies has a crucial role.

Having realized how important learning strategy use is, researchers, such as Macaro (2010), Grenfell and Harris (2002), Brown (2001, 2007), Grenfell and Macaro (2007), Oxford (1990, 1993, 1995), Cohen (2003, 2008), Wenden and Rubin (1987), O'Malley and Chamot (1990), Griffiths (2008), and Scarcella and Oxford (1992), have tried to define learning strategies and language learning strategies. Although, as Macaro (2010) states, there is disagreement in defining strategy, learning strategy, and language learning strategy. According to Oxford (1990), "learning strategies are specific actions taken by the learner to make learning easier, faster, more enjoyable, more selfdirected, more effective, and more transferable to new situations" (p. 8).

For language learning strategies (LLS), O'Malley and Chamot (1990) define them as "the special thoughts and behaviors that individuals use to help them comprehend, learn, or retain new information" (p. 1). In another study, Oxford (1993) provides another definition by emphasizing a 'conscious' dimension and states that "they are specific actions, behaviors, steps, or techniques that students employ - often consciously - to improve their progress in internalizing, storing, retrieving, and using the L2" (p. 175). In addition, Cohen (2010) defines 'language learning strategies' as "conscious or semi-conscious thoughts and behaviors used by learners with the explicit goal of improving their knowledge and understanding of a target language" (p. 164).

Having agreed upon some possible ways to identify language learner strategies, many researchers moved on to studying classification schemes. Researchers like Cohen (2008a, 2011), Brown (2007), Grenfell and Harris (2002), and Oxford (1990) offered relatively similar classification schemes of language learning strategies. Considering their classification schemes, there are three main types of classification. A classification of learning strategies can be made by differentiating the strategies that are directly related to learning the language from the strategies employed while using the language that has been learned. Another classification of strategies can be done according to a skill area which can be divided into two major groups: receptive compromising listening and reading skills and productive compromising speaking and writing skills. However, as Singhal (2011) points out, strategies may not be limited to one area. While some specific strategies can be in one single skill area, some other strategies such as vocabulary, translation and grammar strategies cut across all four areas. They can also 
be classified according to their function; cognitive, metacognitive, affective and social strategies are the four classes used by researchers for this category.

\subsection{Reading strategies}

Today, there are several definitions of what reading strategies are. Although there may be some minor differences it is generally accepted that as Erler and Finkbeiner (2007, p. 18) state, they are "intentional actions chosen to facilitate reading at any level of processing". According to Singhal (2011) in the second language learning context, strategies that improve the effectiveness of learning are called as language learning strategies whereas strategies used by the learner to facilitate the reading process and develop comprehension are called comprehension or reading strategies.

Zang et al., (2008) indicate that according to language proficiency, the use of reading strategies shows differences. Higher-proficiency learners utilize reading strategies which involve both top-down and bottom-up strategies during the reading process. They both try to understand the text literarily and utilize the strategies reconstructing, interpreting, summarizing and making inferences in addition to their world/schematic knowledge. On the other hand, low-proficiency pupils have perceptual problems and could not orchestrate their strategy use for reasonable level of comprehension. They spent most of their time for trying to decode, repeating phrases or words, and could not establish links between information, and monitor their interpretation and understanding.

Tsai states (2012) that reading in EFL context is a complex process that requires both lower-level and higher-level processing skills and interaction between L1 and L2 plays an important role in this process. According to Block (1986), EFL readers did not show differences in terms of strategies or patterns of strategies they had used from those of native speakers of English. In other words, second language readers bring with them their knowledge of reading process and of approaches and apply these to specific language features in the text. Therefore, it can be said that development of strategy use is likely to be independent the characteristics of language. In this respect, reading ability can be partially carried from one language to another.

\subsection{Reading strategy classifications}

Researchers have tried to classify the reading strategies for a long time. This has resulted in the identification of the strategies used by learners and researchers tried to classify the reading strategies either as part of language learners' strategies or reading strategies alone. When looked at the literature it is possible to have several classification systems, one of which is done by Oxford (1990) who has several works on language learners' strategy use. Most of the reading strategies chosen for reading strategy instructions are either directly taken or adapted from her studies. As part of 
her classification system of language learner strategies, she names reading strategies and classifies them according to their function.

On the other hand, there are activity-based classifications by various researchers. Since throughout the reading process it is mostly accepted that there are three main reading activities: pre-, while-, and post-reading activities. Researchers like Grabe and Stoller (2001), Wallace (1992), and Zang (2008) organize reading strategies in terms of pre-, during-, and post-reading stages. There are also other classifications given by the researchers such as Brown (2001) and Erler and Finkbeiner (2007). According to them there are two major strategy classes used during the process of reading: top-down and bottom-up. Top-down processes are higher level processes such as using background knowledge or schemata and getting the meaning from the whole text. Bottom-up processes are lower-level processes using words and phrases to understand the text and there are always successful readers and less successful readers.

What has come out as a result of these strategy classification studies is that strategies playing an important role in the development of language proficiency can be taught systematically. Because as Grabe and Stoller (2001) argue, strategic readers understand the goal of reading, have a variety of strategies which they apply effectively in combinations, can monitor comprehension and identify problematic parts and repair effectively. With classified strategy groups at hand strategy-based instruction have been developed. Researchers have begun to propose different frameworks and approaches for reading strategy instruction.

\subsection{Learning styles and strategies}

So, where do learning style preferences and language learning strategy choice meet? Jie (2006) and Hedge (2008) point out that learners' learning styles preferences determine their strategy choices. Although these two terms are very different in their nature, they have a close and complex relationship. Brown (2007) argues that styles vary across individuals but strategies vary within an individual. Brown also says that "many strategies are related to, and actually become the outward manifestation of styles" (p. 27). In addition, Cohen (2011) argues that learners try to relate their preferred learning styles and strategies to each other. For him, by investigating the characteristics of the task together with the learners' preferred learning style, their strategy use can be predicted. This is because the series of strategies that they draw on will likely be consistent with their learning styles.

\subsection{Strategy training}

As a result of understanding the importance of styles and strategies and then classifying them, researchers created the foundation to improve the efficiency of language classes. As such, they have begun to develop strategy-based instruction. 
According to Williams and Burden (2000) there are some common assumptions about strategy training:

that we can identify the strategies used by good language learners

that we can teach these processes to our learners

there will be resulting increase in the learners' effectiveness in learning

that these are the right strategies to teach to all learners (pp. 156 -158).

The underlying premise is that learners cannot be taught everything. As Oxford (1990) argues, in time they have to take responsibility for their own learning, which means they should learn how to learn. Here metacognition plays a great role in the language learning process. According to Anderson (2008), strong metacognitive skills empower the language learner: when learners reflect upon their learning, they become better prepared to make conscious decisions about what they can do to improve their learning. Cohen (2008) says what is important is that learners develop their own strategy knowledge repertoire and also know which strategies will work best for the task at hand and in general.

According to Cohen (2011), among the factors contributing to the effectiveness of strategy instruction with any given learner are the specific learning context and task; learner's background knowledge; goals for learning [Japanese]; style preferences; and language strategy repertoire. According to Rubin, Chamot, Harris, and Anderson (2007), for accurate and reliable Strategy-Based Instruction (SBI) reports, the research and instructional methodology used must be carefully described. This includes "what strategies were taught; how they were taught; the level of explicitness in the instruction; types of activities students were engaged in to practice the strategies; how the use of strategies has been evaluated; the length of time the SBI took; and whether the instruction included metacognitive awareness raising" (p. 155). The effect of strategy instruction on students' self-reports of strategy use as well as proficiency level need to be assessed.

Cohen's (1998) 'Styles and Strategy Based Instruction (SSBI), Chamot et al., (1999)'s 'Cognitive Academic Language Learning Approach (CALLA), and 'Grenfell and Harris' model (1999) can be shown as examples for SBI. In addition to these, Oxford (1990) argues that there are three types of strategy training: awareness training, one-time strategy training, and long-term strategy training. Some researchers, one of whom is Kellerman (1991), advocate that classroom time is so precious that it should not be wasted on extra training. Separate instruction can take place before beginning a course or parallel to the language lessons. But on the other hand, with a different point of view, Grenfell and Harris (2002), who propose an integrated model, suggest that training in strategy use shouldn't be an additional action for a traditional classroom. Instead, communicative competence and learner autonomy should be backed up with it.

Another controversial issue is whether the instruction should be explicit or if it should be done implicitly. According to Chamot (2008), teachers should adopt explicit instruction by integrating it into the regular course work. Chamot (2008) points out 
that although giving instruction in the target language may work for high-level language students; it will not be feasible for beginner-level students who do not have the proficiency to understand the instruction. Therefore, in a classroom in which all students and the teacher can speak the same first language, language learning strategy instruction can be given in the first language.

\subsection{Reading strategy instruction}

After decades of hard work, it has been found out that reading can be improved successfully by teaching appropriate strategies as well as when, where, why, and how to apply them. Carrell (1985) points out that students' reading comprehension can be improved by teaching top-level rhetorical organization of texts explicitly and overtly. One of the early studies on systematic strategy training was conducted by Palinscar and Brown (1984) who introduced the reciprocal method. According to this method teachers and students work together and discuss about a text in turns. Another reading strategy instruction framework is developed by McNamara (2004) named SelfExplanation Reading Training (SERT). The aim of this framework is to help learners to exploit active reading strategies such as comprehension monitoring, paraphrasing, elaboration, logic or common sense, predictions, and bridging and so on as well as to improve general reading comprehension and overall class performance by selfexplaining.

More recently, Macaro and Erler (2008) conducted a strategy instruction program with 62 eleven-twelve-year-olds during 14 months. The instruction had these five steps. These steps consist of increasing students' awareness levels, showing them how to use the strategies by modelling, helping them to put the strategies into use, then withdrawing the help gradually, and assessing their attitudes towards reading. Their results suggest that through instruction learners' comprehension of both simple and more elaborate texts increased, changes occurred in the way they use strategies and their attitudes towards reading improved. Students began to use strategies in combination and they become more self-autonomous.

Another well-known and commonly applied instruction framework is Metacognitive Strategy Training (MST). According to Carrell, Pharis and Liberto (1989) metacognition is an important aspect of strategic reading. When learners are conscious of their own progress, it is highly likely to achieve long lasting results. In their study in which they applied semantic mapping and Experience-Text-Relationship methods, they found out that metacognitive strategy training in these methods were affective in developing second language reading.

Considering the aforementioned issues, the present study seeks answers to the following research questions (RQs):

1. Does the eight-week reading strategy training have an effect on students' reading skills? Do students' reading scores differ significantly after the intervention between 
the experimental and control groups when their initial achievement scores are controlled?

2. Does the eight-week reading strategy training have an effect on students' reading strategy use? Are students' reading strategy use scores for the experiment and control groups significantly different when their initial reading strategy use scores are controlled?

3. After the initial pre-intervention learning style scores are controlled, do differences exist in students' learning style preferences based on the change in their reading strategy use upon completion of the eight-week reading strategy training program?

\section{Method}

This experimental study was designed to identify the language learning style preferences, reading strategy use and proficiency levels of students in 11th grade at a high school in Turkey. Moreover, it aimed to examine the relationship between reading strategy instruction and students' preferred language learning styles, reading strategy use and their proficiency levels. However, since it was not possible to randomize students to treatment and control groups, it would be better to tell that this study has a quasi-experimental design (Cook and Campbell, 1979; White and Sabarwal, 2014).

\subsection{Participants}

This study was conducted in a high school and all the students had already been grouped into their classrooms. Therefore, it was not possible to assign students to treatment and control groups randomly. Instead, purposive sampling design was used in the scope of the study. This method which is a non-probability sampling is often used when the groups are selected according to the judgement of the researcher (Black, 2010). In other words, as Silverman and Marvasti (2008) argue purposive sampling method allows researchers choose the cases because it illustrates some features that researchers are interested in. The participants of this study, who were selected according to the purposive sampling method, were 6511 th grade students from an Anatolian High School in the southwestern city, Turkey. They were able to enroll in this school based on their results on a national entrance examination. Due to this, there were not many differences in terms of their academic achievements. Moreover, they had completed the CEFR A1 and A2 levels in 9th and 10th grades and were supposed to study B1 level. Of the three 11th grade classes, one was chosen as the experimental group (SB) in which the reading strategy training was conducted; whereas the others would be the control groups (SC, SA).

\subsection{Data collection tools}

In the scope of this study, the expectation was to look for any indicator of the effect of strategy instruction on students' language strategy choice, learning style preferences and their proficiency levels. For this purpose, Key English Test (KET) developed by Cambridge University Press, Learning Style Survey (LSS) developed by Cohen, Oxford 
and Chi (2005), and Survey of Reading Strategies (SORS) by Kouider Mokhtari ve Ravi Sheorey (2002) were used. These surveys have been credited as reliable and valid tools around the world. Before beginning the experiment, however, they were each applied to a pilot group of 25 students who were chosen from the population of 10 th graders in order to calculate the reliability coefficient. As a result of the statistical analysis, the Cronbach's Alpha coefficient for item reliability of KET was found as .76. When looked at the reliability of KET in all three groups before and after the experiment the Cronbach's Alpha coefficient was .86.

To identify the students' learning style preferences and their strategy use, LSS developed by Cohen, Oxford and Chi (2005) was chosen. The survey consists of 110 items with five-point Likert scale $(0=$ never $-4=$ always $)$. With eleven major activities representing twelve different aspects of learning styles, LSS is designed to assess the general approach to learning and indicate the overall style preference. As a result of the statistical analysis of the data obtained from the piloting group, Cronbach's Alpha coefficient for item reliability was .895 and its sub group reliability was calculated as .85. From the treatment and control groups reliability analysis of LSS was .91 for sub groups and .94 for items.

SORS by Kouider Mokhtari ve Ravi Sheorey (2002) provides information about the various strategies used when reading school-related academic materials in English such as course book, examinations etc. It consists of 30 statements with 5-point Likert type scale ranging from $1=$ never and $5=$ always. Statistical analysis of the SORS results from piloting group, the Cronbach's Alpha value was .90 for each item and .93 for subgroups and overall strategy values.

\subsection{Procedure}

There were two phases in this study: (1) a data collection phase which included data collection on learning style preferences, learning strategy use, and reading proficiency levels both before and after the implementation of strategy instruction; and (2) a reading strategy instruction phase which included choosing appropriate materials; implementation; and obtaining of data from student journals and teacher's logs. In the first phase, all the necessary data were collected and analyzed in terms of frequencies and percentages. Then, students were told about the scope of the study. In the second phase of this study, it was crucial to determine the strategies to be taught and the materials appropriate for instruction of these strategies. Choosing a framework for instruction was essential as almost all the research argues that it is the most important part of strategy-based instruction.

In accordance with the data obtained from SORS, the strategies of predicting, making inferences, translating (finding patterns), summarizing, and clarifying were chosen along with grouping strategy. Additionally, all the activities that were part of this intervention had been orchestrated according to the framework proposed by Chamot, Anstrom, Bartoshesky, Belanger, Delett, Karwan, Meloni, and Keatley (2003). The 
framework was created as a five-stage - preparation, presentation, practice, evaluation, and expansion - guide for strategy instruction.

For each strategy, a teacher-researcher first handed out informative worksheets. The materials for preparation and presentation of the strategies were adapted with written consent from the dissertation of Lee (2007) who also studied the reading strategy instruction in an EFL context. For each strategy, a presentation paper, which was adapted to the Turkish context, was presented to the students. These presentation papers included the information about what the strategy was; why, when, how, and where to use the strategy; how to evaluate it; and also example texts. At this stage researcher presented the usage of the strategy via a power-point presentation, worksheets or online tools.

During the instruction of first strategy, predicting, teacher-researcher used the materials from the book 'High-Interest: Reading Comprehension Skills \& Strategies' published by Saddleback Educational Publishing in 2002. By using the materials, the teacher told about the strategy and its importance by giving examples. Then, further explained how and when to use the strategy with extracts and examples. Meanwhile, students were free to ask any questions that they came up with. Having felt that students did not have any problems, the teacher went on to practice by using extra worksheets. For further practice, several activities for each strategy were taken from the book (High-Interest: Reading Comprehension Skills \& Strategies). Moreover, to increase the interest of the students, some interactive exercises from the following addresshttp://www.tv411.org/reading/understanding-what-you-read/strategiesbetter reading/activity were used together with some presentations. At the end of each session students and teacher discussed the strategy at hand and tried to find new ways of using.

\subsection{Data analysis}

The data derived from the instruments were organized using SPSS 23 and the findings were examined and compared in terms of the main and interaction effects of reading strategy training and the effects of changes in reading strategy use on students' language learning style preferences. In this way, any possible relationship between treatment and control groups in terms of their language learning style preferences, reading strategy usage and their language proficiency levels was sought.

\section{Findings}

1. Does the eight-week reading strategy training have an effect on students' reading skills? Do students' reading scores differ significantly after the intervention between the experimental and control groups when their initial achievement scores are controlled?

In order to investigate the effect of the eight-week reading strategy training on students' language achievements, a one-way between groups analysis of covariance was conducted. According to Tabachnick and Fidell (2007), and Pallant (2011) this 
technique can be used when there are two groups in a pre-test/post-test design. The scores from the pre-test are treated as covariates to control the pre-existing differences between groups. In addition, it is useful when the groups were unable to be assigned randomly. The independent variable was the intervention (experiment and control) and the dependent variable was the students' scores on Key English Test administered after the intervention was completed. Students' achievement scores on the preintervention administration of KET were used as the covariance in this analysis.

Table 1. shows the mean scores and standard deviations for both groups

\begin{tabular}{|c|c|c|c|c|c|}
\hline \multirow{2}{*}{ Groups } & \multirow{2}{*}{$\mathrm{N}$} & \multicolumn{2}{|c|}{ Pre-Intervention KET Score } & \multicolumn{2}{|c|}{ Post-Intervention KET Score } \\
\hline & & $\mathrm{M}$ & $\mathrm{SD}$ & $\mathrm{M}$ & $\mathrm{SD}$ \\
\hline Experimental & 23 & 39.30 & 12.900 & 36.78 & 12.041 \\
\hline Control & 39 & 39.49 & 13.000 & 37.59 & 11.137 \\
\hline Total & 62 & 39.42 & 12.857 & 37.29 & 11.389 \\
\hline
\end{tabular}

Preliminary checks were done to guarantee that there was no violation of the assumptions of normality, linearity, homogeneity of variances, homogeneity of regression slopes, and reliable measurement of covariate. After adjusting for the preintervention scores, there was no significant difference between experiment $(\mathrm{M}=36.78$, $\mathrm{SD}=12.041)$ and control $(\mathrm{M}=37.59, \mathrm{SD}=11.137)$ groups in post-intervention scores on the Key English Test, F $(1,59)=.124, \mathrm{p}=.39$, partial eta squared $=.002$. There was a strong relationship between the pre-intervention and post-intervention scores on the Key English Test, as indicated by a partial eta squared value of .60

RQ2: Does the eight-week reading strategy training have an effect on students' reading strategy use? Are students' reading strategy use scores for the experiment and control groups significantly different when their initial reading strategy use scores are controlled?

The second research question aimed to identify whether the eight-week intervention affected the reading strategy use of students. Controlling for their initial scores, a similar one-way between groups of covariance was conducted to determine if there was a statistically significant difference between experiment and control groups on the scores they got after the intervention. The independent variables were the experiment and control groups and the dependent variable was the students' post reading strategy scores obtained from SORS. In addition, students' pre-intervention reading strategy scores were used as the covariance in the analysis.

Table 1. Mean scores and standard deviations of pre- and post-reading strategy use

\begin{tabular}{|c|c|c|c|c|c|}
\hline \multirow[t]{2}{*}{ Groups } & \multirow[t]{2}{*}{$\mathrm{N}$} & \multicolumn{2}{|c|}{$\begin{array}{l}\text { Pre-Intervention Reading Strategy } \\
\text { Use Score }\end{array}$} & \multicolumn{2}{|c|}{$\begin{array}{l}\text { Post-Intervention Reading Strategy } \\
\text { Use Score }\end{array}$} \\
\hline & & $\mathrm{M}$ & SD & $\mathrm{M}$ & SD \\
\hline Experimental & 23 & 3.59 & .460 & 3.85 & .535 \\
\hline Control & 39 & 3.49 & .539 & 3.46 & .493 \\
\hline Total & 62 & 3.52 & .510 & 3.60 & .540 \\
\hline
\end{tabular}

According to a preliminary analysis, as in research question one, there was no violation of the assumptions. Thus, the analysis was conducted. After adjusting for the 
pre-intervention scores, there was a significant difference between the experiment (M $=3.85, \mathrm{SD}=.535)$ and control groups $(\mathrm{M}=3.46, \mathrm{SD}=.493)$ on post-intervention scores on SORS, F $(1,59)=8.856, p=.004$, partial eta squared $=.131$. There was a strong relationship between the pre-intervention and post-intervention scores on the SORS, as indicated by a partial eta squared value of .28 .

RQ3: After the initial pre-intervention learning style scores are controlled, do differences exist in students' learning style preferences based on the change in their reading strategy use upon completion of the eight-week reading strategy training program?

To be able to investigate research question three, students were grouped in terms of the type of change in their strategy use. Students whose reading strategy use increased and students whose reading strategy use decreased or did not change were labeled as increased and decreased reading strategy use groups.

The relationship between the students' language learning styles and the direction of change in their reading strategy scores was investigated using Pearson productmoment correlation coefficient (Pearson $r$ ). Pearson $r$ is used when there are interval level continuous variables. Also, it can be used when there are one continuous variable and one dichotomous variable (Pallant, 2011). According to the results, there are medium, negative correlations between the students' reading strategy score changes and their perceiving themselves as random intuitive $\mathrm{r}=-.324, \mathrm{n}=62, \mathrm{p}<.01$; concrete sequential $\mathrm{r}=-.309, \mathrm{n}=62, \mathrm{p}<.02$; synthesizer $\mathrm{r}=-.466, \mathrm{n}=62, \mathrm{p}<.001$; and impulsive $\mathrm{r}=-.301, \mathrm{n}=62, \mathrm{p}<.02$. In addition, there are small, negative correlations between the students' reading strategy score changes and their perceiving themselves as visual learners $\mathrm{r}=-.277, \mathrm{n}=62, \mathrm{p}<.03$ and reflective learners $\mathrm{r}=-.288, \mathrm{n}=62, \mathrm{p}<.03$. Table 3 shows the correlations among students' achievement grades, the direction of the change in their reading strategy scores and their perceived learning styles.

A 2 by 2 between groups analysis of covariance of the students in the experiment and control groups was conducted to assess the effectiveness of the eight-week reading strategy training on language learning style preferences. This analysis is used when there are two independent categorical variables and one and more continuous covariates (Pallant, 2011). The independent variables were groups (experimental and control) and reading strategy change groups (increased and decreased). The dependent variable was the post-intervention language learning style scores. Scores obtained from pre-intervention LLSS were used as a covariate to control for individual differences. 
Table. 3 Pearson product correlation coefficients

\begin{tabular}{|c|c|c|c|c|c|c|c|c|c|c|c|c|c|c|c|c|c|c|c|c|c|c|c|c|c|}
\hline & 1 & 2 & 3 & 4 & 5 & 6 & 7 & 8 & 9 & 10 & 11 & 12 & 13 & 14 & 15 & 16 & 17 & 18 & 19 & 20 & 21 & 22 & 23 & 24 & 25 \\
\hline 1. Ket Score & 1 & & & & & & & & & & & & & & & & & & & & & & & & \\
\hline 2. Reading Str. Group &,- 008 & 1 & & & & & & & & & & & & & & & & & & & & & & & \\
\hline 3. Visual & ,002 &,$- 277^{*}$ & 1 & & & & & & & & & & & & & & & & & & & & & & \\
\hline 4. Auditory & 017 & -240 &, $428^{\text {**t }}$ & 1 & & & & & & & & & & & & & & & & & & & & & \\
\hline 5. Tactile Kinesthetic &,- 050 &,- 089 &, 217 &, $401^{\text {*t* }}$ & 1 & & & & & & & & & & & & & & & & & & & & \\
\hline 6. Extraverted & 091 &,- 224 &,- 004 &, $327^{\text {the }}$ &, $403^{* * *}$ & 1 & & & & & & & & & & & & & & & & & & & \\
\hline 7. Introverted & ,033 &, 021 & $313^{*}$ & ,119 & ,153 & ${ }^{-}, 030$ & 1 & & & & & & & & & & & & & & & & & & \\
\hline 8. Random Intuitive &,- 080 &,$- 324^{*}$ &, $410^{\text {t*k }}$ &, 043 &, $299^{*}$ &, $375^{\text {*** }}$ & 205 & 1 & & & & & & & & & & & & & & & & & \\
\hline 9. Concrete Seq. & ,180 &,$- 309^{*}$ &, $502^{* * *}$ & $342^{\text {tht }}$ & ,127 & 170 &, $447^{\text {tak }}$ & $306^{*}$ & 1 & & & & & & & & & & & & & & & & \\
\hline 10. Closure Oriented &, $291^{*}$ &,- 199 &, $425^{\text {*kw }}$ & ,162 &,- 122 & ,145 &, $315^{*}$ &, $275^{*}$ &, $616^{* *}$ & 1 & & & & & & & & & & & & & & & \\
\hline 11. Open & -,086 &, 056 &,- 041 & 235 &, $273^{*}$ & ,168 &, $258^{*}$ & -,181 & ,196 & - 238 & 1 & & & & & & & & & & & & & & \\
\hline 12. Global &,- 078 &,- 053 &, $314^{*}$ & ,143 &, $524^{* * *}$ &, $312^{*}$ & ,102 &, $292^{*}$ &,- 005 &, 001 & 091 & 1 & & & & & & & & & & & & & \\
\hline 13. Particular &, $257^{*}$ &,- 176 &, $338^{* *+}$ &, $385^{\text {wht }}$ &, $331^{* * *}$ & 249 &, $425^{\text {**t }}$ & 220 & ,481** &, $422^{* *}$ & ,149 & 069 & 1 & & & & & & & & & & & & \\
\hline 14. Synthesizing &, 026 &,$- 466^{* *}$ &, $421^{* *}$ &, $436^{4 * x}$ &, $267^{*}$ &, $346^{* *}$ &, $284^{*}$ &, $578^{* *}$ &, $580^{* *}$ &, $411^{* *}$ &, 014 &, 228 &, $399^{* *}$ & 1 & & & & & & & & & & & \\
\hline 15. Analytic & 158 & 087 &, $293^{*}$ & ,206 & ,175 & ,079 &, $337^{* * *}$ &, 029 &, $522^{\star *}$ & $308^{*}$ & ,338 & -,068 &, $587^{* *}$ & ,191 & 1 & & & & & & & & & & \\
\hline 16. Sharpener & ,179 &,- 239 &, $509^{*+*}$ &, $312^{*}$ & 130 & ,136 &, $303^{*}$ & $429^{\text {t*t }}$ & , $609^{* *}$ & ,691* &,- 067 & ,146 &, $492^{* *}$ &, $521^{* *}$ &, $394^{* * *}$ & 1 & & & & & & & & & \\
\hline 17. Leveler &, 058 &,- 210 &, $294^{*}$ &, $425^{\text {t*t }}$ &, $305^{*}$ & ,107 &, $414^{* * *}$ & ,122 &, $456^{\text {*** }}$ & ,193 &, $274^{*}$ &, 227 & $346^{\text {** }}$ & , $415^{\text {t*t }}$ &, $326^{\text {t*t }}$ &, $402^{\text {t*t }}$ & 1 & & & & & & & & \\
\hline 18. Deductive &, $253^{*}$ & -, 188 & ,219 & ,022 &,- 021 &, $280^{*}$ &, $267^{*}$ & , $371^{* * *}$ &, $380^{* *}$ &, $599^{* *}$ &,- 200 & ,076 & $490^{* *}$ &, $305^{*}$ & ,210 &, $469^{\text {t*t }}$ & ,145 & 1 & & & & & & & \\
\hline 19. Inductive & , 196 &,- 054 &, $332^{* *+}$ &, $277^{*}$ & ,115 &, 044 &, $367^{\text {the }}$ &, 105 &, $343^{* *}$ &, $295^{*}$ &, 232 &, 212 &, $498^{* *}$ &, $261^{*}$ &, $503^{\text {w* }}$ &, $378^{\text {tw }}$ &, $324^{*}$ &, $332^{* *}$ & 1 & & & & & & \\
\hline 20. Field Independent & ,189 &,- 233 &, $457^{4 * *}$ &, 117 & 130 &, 004 &, $315^{*}$ &, $383^{\text {** }}$ &, $435^{\text {** }}$ &, $446^{* *}$ &,- 221 &, 091 &, $535^{* *}$ &, $361^{* *}$ &, $395^{\text {*** }}$ &, $595^{\text {t*x }}$ &, $414^{* * *}$ &, $492^{* *}$ &, $498^{* t h}$ & 1 & & & & & \\
\hline 21. Field Dependent &,- 080 &, 036 &, 165 & 164 &, $518^{* *}$ &, 001 &, $287^{*}$ &, $263^{*}$ &, 173 &, 045 &, 222 &, $292^{*}$ &, $263^{*}$ &, 170 & 200 &, $254^{*}$ &, $470^{* * *}$ & ,063 &, $278^{*}$ & ,208 & 1 & & & & \\
\hline 22. Impulsive & , 186 &,$- 301^{*}$ & , 158 & ,133 &, $288^{*}$ &, $305^{*}$ &, 079 &, $323^{*}$ & ,248 &, 214 &,- 047 &, 177 & ,344 &, $270^{*}$ & , 153 &, $327^{* *}$ & , 182 &, $400^{* *}$ &, $297^{*}$ &, $497^{* *}$ & 168 & 1 & & & \\
\hline 23. Reflective &, $320^{*}$ &,$- 288^{*}$ &, $289^{*}$ & , $339^{\text {*tw }}$ & ,117 &, 229 & , $332^{\text {*** }}$ & ,248 &, $471^{* *}$ &, $284^{*}$ & ,015 &,- 023 & $415^{\text {** }}$ &, $427^{* *}$ & ,126 &, $334^{* * *}$ &, $423^{* * *}$ &, $373^{\text {*** }}$ & ,232 &, $403^{\text {t*t }}$ & , 174 & ,368 & 1 & & \\
\hline 24. Metaphoric &, $297^{*}$ & -,182 &, $384^{* * *}$ &, $259^{*}$ & ,203 & , 053 & , 432 & ,216 &, $465^{\text {*** }}$ &, $530^{* * *}$ & -,099 & ,037 &, $579^{* *}$ & , 377 &, $373^{\text {t*t }}$ &, $556^{\text {*t* }}$ & ,232 & , 483 & , $422^{\text {tot }}$ &, $496^{\text {*** }}$ &, $322^{*}$ &, $294^{*}$ & ,378 & 1 & \\
\hline 25. Literal & ,114 &,- 119 & , 180 & ,131 & ,146 & ,207 &, $250^{*}$ & ,201 &, $319^{*}$ & ,239 &, $252^{*}$ & ,142 & , $377^{* *}$ &, $266^{*}$ &, $399^{\text {**t }}$ &, $342^{* * *}$ &, $462^{* * *}$ & ,208 & , 280* & ,214 & $341^{\text {*t* }}$ &,- 031 & ,211 & , 049 & 1 \\
\hline
\end{tabular}

*. Correlation is significant at the 0.05 level (2-tailed).

$* *$. Correlation is significant at the 0.01 level (2-tailed). 
Preliminary checks were carried out to see whether there was no violation of the assumptions. However, among these variables, the one labeled 'post-random intuitive' violated the homogeneity of variances assumption. So, it was excluded from the followup analyses. Table 4 shows the descriptive statistics for three dependent variables together with their covariates.

Table 4. Mean scores and standard deviations of pre- and post- concrete sequential, synthesizer and impulsive style preferences

\begin{tabular}{|c|c|c|c|c|c|c|c|c|c|c|c|c|c|c|}
\hline & & & \multicolumn{2}{|c|}{$\begin{array}{l}\text { Pre- } \\
\text { Concrete } \\
\text { Sequential }\end{array}$} & \multicolumn{2}{|c|}{$\begin{array}{l}\text { Post- } \\
\text { Concrete } \\
\text { Sequential }\end{array}$} & \multicolumn{2}{|c|}{$\begin{array}{l}\text { Pre- } \\
\text { Synthesizer }\end{array}$} & \multicolumn{2}{|c|}{$\begin{array}{l}\text { Post- } \\
\text { Synthesizer }\end{array}$} & \multicolumn{2}{|c|}{$\begin{array}{l}\text { Pre- } \\
\text { Impulsive }\end{array}$} & \multicolumn{2}{|c|}{$\begin{array}{l}\text { Post- } \\
\text { Impulsive }\end{array}$} \\
\hline & & & $\mathrm{M}$ & $\mathrm{SD}$ & $\mathrm{M}$ & $\mathrm{SD}$ & $\mathrm{M}$ & SD & $\mathrm{M}$ & $\mathrm{SD}$ & $\mathrm{M}$ & $\mathrm{SD}$ & $\mathrm{M}$ & SD \\
\hline \multirow[b]{4}{*}{ 亏్ } & \multirow{3}{*}{ 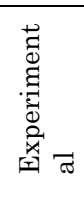 } & $\begin{array}{l}\text { Reading Str. Use } \\
\text { Increased }\end{array}$ & 16.0 & 3.37 & 17.7 & 3.1 & 15.9 & 2.3 & 16.1 & 2.5 & 6.8 & 2.2 & 7.0 & 1.9 \\
\hline & & $\begin{array}{l}\text { Reading Str. Use } \\
\text { Decreased }\end{array}$ & 15.3 & 2.80 & 11.8 & 3,0 & 13.0 & 2.7 & 13.1 & 1.9 & 6.1 & 1.1 & 5.1 & 2.4 \\
\hline & & $\begin{array}{l}\text { Reading Str. Use } \\
\text { Increased }\end{array}$ & 15.8 & 3.48 & 15.4 & 4.4 & 16.4 & 2.4 & 15.6 & 2.7 & 7.0 & 2.0 & 7.1 & 1.7 \\
\hline & 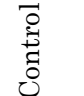 & $\begin{array}{l}\text { Reading Str. Use } \\
\text { Decreased }\end{array}$ & 15.4 & 3.19 & 14.3 & 4.7 & 14.4 & 2.6 & 13.1 & 3.0 & 7.0 & 2.6 & 5.9 & 2.5 \\
\hline
\end{tabular}

First post concrete-sequential scores were investigated. After adjusting preintervention concrete sequential scores, a significant interaction effect was seen. F (1, $57)=5.28, \mathrm{p}<.03$, with a small effect size (partial eta squared $=.085$ ), was observed. In terms of main effects, the reading strategy training was not statistically significant, $\mathrm{F}(1,57)=.017, \mathrm{p}>.05$. However, the effect of change in reading strategy use was statistically significant, $\mathrm{F}(1,57)=116.27, \mathrm{p}<.001$. Table 4 shows the descriptive statistics for concrete sequential, synthesizing and impulsive scores according to the groups and the direction of change in reading strategy use.

These results suggest that students who increased their reading strategy use (experimental: $\mathrm{M}=17.52, \mathrm{SD}=.854$; control: $\mathrm{M}=15.33$, $\mathrm{SD}=.830$ ) and students who decreased their strategy use (experimental: $\mathrm{M}=12.10, \mathrm{SD}=1.438$; control: $\mathrm{M}=14.55$, $\mathrm{SD}=.769$ ) from the two groups showed different tendencies in terms of their language learning style preferences. Figure 1 shows a profile plot for post concrete sequential scores for the two groups. 


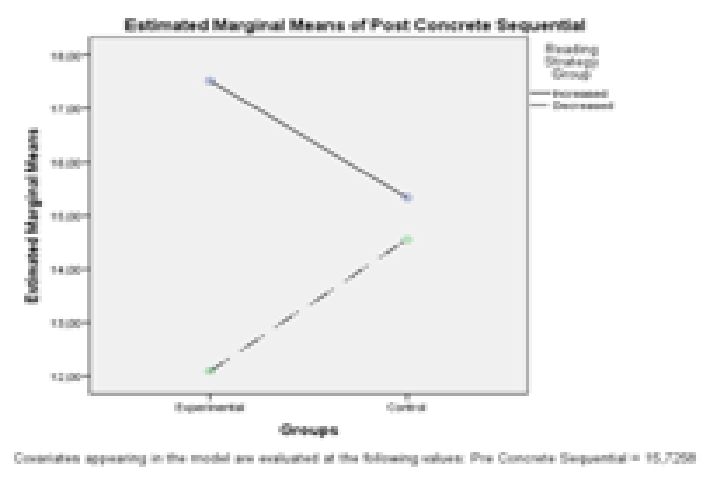

Figure 1. Estimated marginal means of post concrete sequential

As it can be understood from Figure 1, after the intervention, the gap between the students who increased their reading strategy use and who decreased it is wider than the control group. That is, in the experiment group, students who increased their reading strategy use as a result of the reading strategy training also stated that they feel more concrete sequential more often than the students who were in the control group who also increased their reading strategy use. In other words, although students may change their strategy use as a result of the natural outcome of their education, these findings indicate that if students are given training and shown how to utilize certain strategies while reading, this may cause them to become more concrete sequential in terms of how they handle reading.

Next, the analysis was repeated for the synthesizing group with the same independent variables. This time, the dependent variable was the students' postimplementation synthesizing scores; whereas the covariate was their initial preintervention survey scores.

If a student perceives herself/himself as having a synthesizing learning style, it means s/he can guess meanings and predict outcomes well. Interestingly, the analysis did not yield any significant interaction effect, $\mathrm{F}(1,57)=.003, \mathrm{p}>.05$, partial eta squared $=0$. In terms of main effects, the training, $\mathrm{F}(1,57)=8.092, \mathrm{p}>.05$, partial eta squared $=.025$, and the direction of change, $\mathrm{F}(1,57)=3.649, \mathrm{p}>.05$, partial eta squared $=.06$, did not have any significant effects on the students' language learning style preferences. Figure 2 shows the profile plot for synthesizing learning style. 


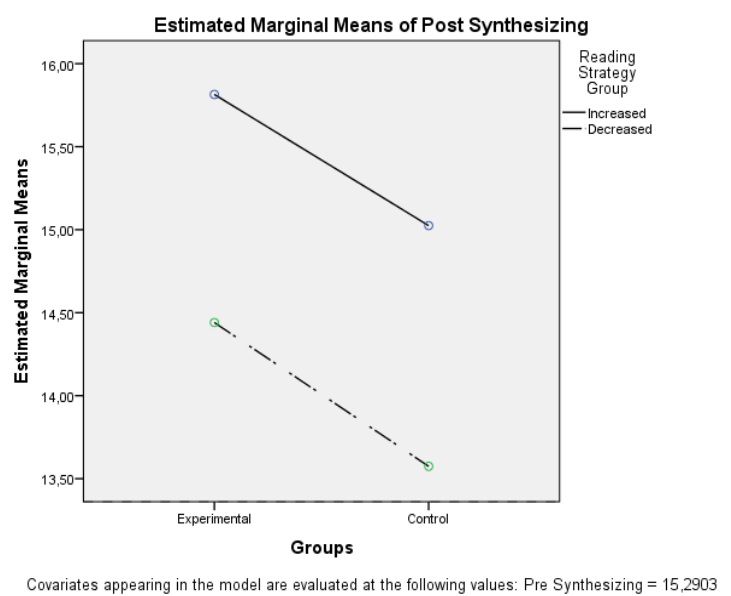

Figure 2 Estimated marginal means of post synthesizing

Finally, the last analysis was carried out in terms of impulsive language learning style in order to investigate if there was any significant interaction effect of reading strategy training and the direction of change in students' reading strategy use. The independent variables were the same as in the previous tests; however, students' postintervention impulsive scores were used as the dependent variable and their preintervention impulsive scores were used as the covariate.

As a result of the analysis, no interaction effect was found, $F(1,57)=.06, p>.05$, partial eta squared $=.001$. There was a main effect on the direction of change in reading strategy use, $\mathrm{F}(1,57)=6.274, \mathrm{p}<.05$, partial eta squared $=.099$, whereas reading

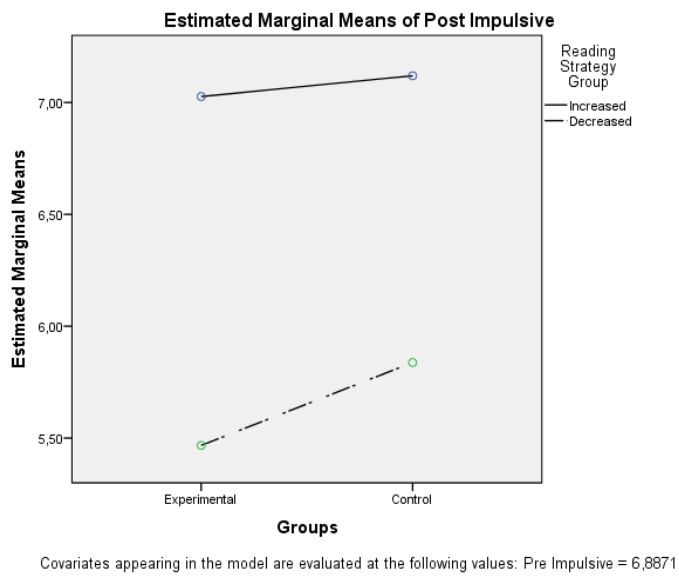

Figure 2 Estimated marginal means of post impulsive 
strategy training did not have any main effect, $\mathrm{F}(1,57)=.166, \mathrm{p}>.05$, partial eta squared.003.

\section{Discussion}

It is generally accepted that reading is a complicated process in which learners employ several strategies to form an understanding. In scope of this current study one of the points investigated is whether reading strategy training has any effect on students reading proficiency levels. According to the findings, it can be stated that the reading strategy training which lasted for eight weeks do not have a significant impact on student reading achievement scores which is not in line with literature. However, researchers such as Mohammadi, Birjandi and Maftoon (2015), Carrell, Pharis and Liberto (1989) and Fehrenbach (1991) argue that it is possible to increase students' reading comprehension levels with reading strategy training. On the other hand, there are studies that provide similar findings with this study. For example, Alharbi (2015) state that different reading strategies do not lead to an increase in reading comprehension.

Another point that is investigated is whether reading strategy training has effects on students reading strategy use. In literature, as Cohen (2011) and Macaro and Erler (2008) argue, strategy training has positive effects on learners' strategy choice and use. In this respect, the findings of this current study indicate similar results. Accordingly, it can be stated that reading strategy training significantly affects students' reading strategy use. That is, it may not be wrong to reach the conclusion that reading strategy training increase student awareness and improves their strategy use.

Another issue is that students may have different tendencies in this context in terms of their language learning style preferences which have connections with other individual differences. Cohen (2003) and Dörnyei (2005) state that there is a connection between strategy use and learning styles. Uhrig (2015) also argues that the strategies students employ emerges as a result of their learning style and task engagement. In this vein, it is possible to find several studies in the literature on the relationship between reading strategies and learning styles. For example, Kirby (1988) states that strategies and styles are all integrated parts of information processing in reading. He investigates reading strategy use in relation to style preferences. A student who has a global style uses strategies to avoid dealing with the details of the text by using the contextual and available information given. On the other hand, an analytic student uses strategies to pay attention to the details and relies on the information on the page. Meanwhile, a synthesizer student uses strategies in a mixed and integrated way.

The results of correlation analysis of this study indicate similar results in line with the literature. Accordingly, it can be stated that there are correlations between students' reading strategies and their learning style preferences. In the current study, medium negative correlations are found between reading strategy scores and students' learning styles in random intuitive, concrete sequential, synthesizer, and impulsive style dimensions whereas there are small negative correlations exist in visual and 
reflective style dimensions. Alharbi's (2015) study shows similar results. In this study reading strategies may have an impact on low visual style learners' reading comprehension.

There are other studies which point out the correlation between reading strategy use and learning styles. In one of these, Gürses and Bouvet (2016) investigate reading comprehension and learning styles in relation to reading strategy use. They found that converging learning styles influence perceived use of reading strategies. Similarly, Tsai (2012) points out that there is a high correlation between reading strategies, learning styles and motivation. Moreover, Young (2006) argues in her study that style factors, together with other factors, correlate with language learning strategies. Accordingly, she points out that if activities in a training program are not provided according to the style preferences of students, then there is a risk of failure. Jafarpanah and Farahian (2016) who found a similar relationship between reading strategy use and learning styles emphasize that "visual, closure-oriented and synthesizing styles have the strongest correlation with metacognitive reading strategy" (p. 48). In these studies, the relationship between reading strategies and learning styles is handled in a rather linear way. They either state the correlation or mention the effect of learning style preferences on student reading strategy use.

However, in the scope of this study, the effect of learning style preferences on reading strategy use is not the main focus. Instead, the investigation is on the interactional effect of reading strategy training between students' learning styles and their reading strategy use. That is, this study investigates whether reading strategy training can have any effect on students' perceived learning styles. According to the findings, it may be argued that reading strategy training may have an effect on students' learning style preferences in concrete-sequential style dimension. The reading strategy training may lead some students to feel more concrete-sequential. In other words, when students have increased their awareness regarding reading strategies and increased their reading strategy use frequency after they have got a meta-cognitive reading strategy training, they can cope with the information presented to them in a more sequential way than before and they tend to follow logical stepwise paths in finding solutions.

Nevertheless, in literature, there are not so many studies dealing with the effect of reading strategy training on style preferences. In one of these few studies, Caroll, Pharis and Liberto (1989) argue that there is a significant aptitude-by-treatment interaction when students' language learning style preferences are taken into consideration. This means that the training they have conducted seems to be related to differences in the learning styles of students. Although their findings indicate such an effect, they do not state in which style dimension the differences occur. In another study, Swan (2015) deals with reading strategy training and learning styles in a similar linear way which is different from the current study as well. He states that students with different learning styles may respond to reading strategies differently. While 
active learners perform better than when using the keyword and question and answer strategies, sensitive and sequential learners perform better with rereading strategy.

All in all, it can be said that most of the studies in literature deal with learning styles and reading strategies in an isolated and linear way and do not indicate any effect of reading strategy training on learning style preferences. In this vein, the current study, which indicates that reading strategy training may have effect on students' learning style preferences, may fill a gap in the literature in terms of its findings.

\section{Conclusion}

This study provides some information regarding language learning styles and strategies. It provides supporting evidence about the effect of metacognitive reading strategy training on student reading strategy use preferences. As a result of the training, it can be stated that students' reading strategy use has increased significantly in favor of the experimental group. However, in terms of academic achievement scores, no significant results have been obtained. That is, it can be said that metacognitive strategy training may not affect student success in reading classes in the short term.

In addition to the above findings, the present study provides some possible effects of reading strategy training on students' language learning style preferences. When the correlations between the students' reading strategy use and their learning style preferences are investigated, it is found out that not all of the style preferences have significant correlations. Only the three style dimensions which are concrete-sequential, synthesizing and impulsive have moderate correlation. Further analysis indicates a change in the concrete-sequential style dimension.

As a result of the further analysis, it can be stated that when students are given a metacognitive strategy training, this may result in students approaching reading activities in a more organized way. After such a training, students who are detail oriented and have problems dealing with abstract ideas, making inferences when something is not stated clearly, answering open ended questions or seeing the big picture may shift their style preference more than those who do not get such training.

All in all, it can be said that metacognitive reading strategy training may not improve student reading proficiency levels in the short term. Yet, it improves student reading strategy awareness and increases the frequency of usage. It may also have effects on student language learning style preferences in terms of becoming more concretesequential when compared to students who have not taken any specific training. However, to reach more sound conclusions similar studies should be carried out with more participants. In addition, to have a better idea of the time effect on students' reading strategy and learning style preferences, further studies may focus on longitudinal research in which the same instruments are used at certain time intervals. 
Finally, pedagogical implications like adjusting teaching styles or materials can be tested for better learner experiences.

There are limitations in this study. The data were collected from a relatively small group of students in only one public high school. In further studies, it could be better to design studies which will cover more schools from different parts of the country. Only two of the individual variables were investigated (language learning styles and reading strategy uses) and other individual and/or group variables were not taken into consideration. Moreover, the intervention took only eight weeks and this might be longer. The data were collected only before and after the intervention. Maybe, it would be better to collect data four times or more to create a time series and to be able to track the changes in a better way. This calls for more research which will be longitudinal and in which more students take part in. In the current study only the immediate effect of reading strategy training were investigated. However, besides examining immediate effect of intervention, examining long-terms effects can reveal more information. In this way it could be possible to reach conclusions in terms of the differences between immediate and long-terms effects of reading strategy training on language learning styles.

\section{Acknowledgement}

This study grows out of an MA thesis titled as "The Effect of Reading Strategy Training on High School Students' Learning Styles”. We would like to thank Dr. Eda Üstünel and Dr. Oya Büyükyavuz for their contributions to the thesis. We are also grateful for constructive comments from anonymous reviewers and editors for their insightful comments and careful reading of the manuscript. Finally, we would like to thank all the students who took part in this study

\section{References}

Alharbi, M. A. (2015). Reading strategies, learning styles and reading comprehension: A correlation study. Journal of Language Teaching and Research, 6(6), 1257-1268.

Anderson, N. J. (2008). Metacognition and good language learners. In C. Griffiths (Ed.), Lessons from good language learners (pp. 99-109). Cambridge, UK: Cambridge University Press.

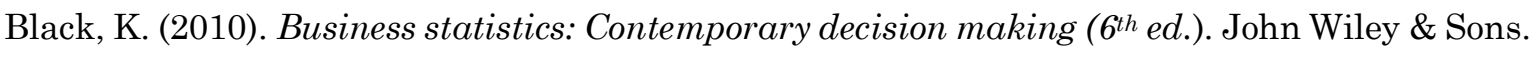

Block, E. (1986). The comprehension strategies of second language readers. TESOL Quarterly, $20(3)$,

463-494.

Brown, H. D. (2001). Teaching by principles: An interactive approach to language pedagogy (2nd ed.). New York, NY: Pearson Education.

Brown, H. D. (2007). Principles of language learning and teaching ( $5^{\text {th }}$ ed.). New York, NY: Pearson Education.

Carrell, P. L. (1985). Facilitating ESL reading by teaching text structure. TESOL Quarterly, 19(4), 727-752.

Carrell, L. P., Pharis, G. B., \& Liberto, C. J. (1989). Metacognitive strategy training for ESL reading. TESOL Quarterly, 23(4), 647-678. 
Chamot, A. U. (2008). Strategy instruction and good language learners. In C. Griffiths (Ed.), Lessons from good language learners (pp. 266-281). Cambridge, UK: Cambridge University Press.

Chamot, A. U., Anstrom, K., Bartoshesly, A., Belanger, A., Delett, J., Karwan, V., \& Keatley, C. (2003). The elementary immersion learning strategies resource guide. Retrieved from www.ncrlc.org/eils/

Chamot, A. U., Barnhardt, S., El-Dinary, P. B., \& Robbins, J. (1999). The learning strategies handbook. White Plains, NY: Addison Wesley Longman.

Cohen, A. D. (2003). The learners' side of foreign language learning: Where do styles, strategies, and tasks meet? International Review of Applied Linguistics in Language Teaching, 41(4), 279-291.

Cohen, A. D. (2010). Focus on the language learner styles, strategies and motivation. In N. Schmitt (Ed.), An introduction to applied linguistics (2 ${ }^{\text {nd }}$ ed., pp. 161-178). London, UK: Hodder Education.

Cohen, A. D., Oxford, R. L., \& Chi, J. C. (2005). Learning style survey for young learners: Assesing your own learning styles. Retrieved from http://www.carla.umn.edu/about/profi les/Cohen.html

Cohen, A. D. (1998). Strategies in learning and using a second language. London, UK: Longman.

Cohen, A. D. (2007). Coming to terms with language learner strategies: Surveying the experts. In A. D. Cohen, \& E. Macaro (Eds.), Language learner strategies: Thirty years of research and practice (pp. 29-46). New York, NY: Oxford University Press.

Cohen, A. D. (2008). Strategy instruction for learners of Japanese: How do you do it and what's in it for them? In Y. A. Hatasa (Ed.), Gaikokugo to shite no nhongo kyooiku: Takakutei shiya ni motozuku kokoromi 'Japanese as a foreign language education: Multiple perspectives (pp. 45-60). Tokyo: Kurosia Shuppan.

Cohen, A. D. (2011). Method and instruction in second language teaching. In E. Hinkel (Ed.), Handbook of research in second language teaching (pp. 681-698). Abingdon, UK: Routledge.

Cohen, A. D., \& Weaver, S. J. (2006). Styles-and strategies-based instruction: A teachers' guide. Minneapolis: MN: Center for Advanced Research on Language Acquisition, University of Minnesota.

Cook, T. D., \& Campbell, D. T. (1979). Quasi-experimentation: Design \& analysis issues in field settings. Boston, MA: Houghton Mifflin.

Cotteral, S. (2008). Autonomy and good language learner. In C. Griffiths (Ed.), Lessons from good language learners (pp. 110-120). Cambridge, UK: Cambridge University Press.

Dörnyei, Z. (2005). The psychology of the language learner: Individual differences in second language acquisition. Mahwah, NJ: Lawrence Erlbaum Associates Publishers.

Döryei, Z. (2010). The relationship between language aptitude and language learning motivation: Individual differences from a dynamic systems perspective. In E. Macaro (Ed.), Continuum companion to second language acquisition (pp. 247-267). London, UK: Continuum International Publishing Group.

Erhman, M. E., Leaver, B. L., \& Oxford, R. L. (2003). A brief overview on individual differences in second language learning. System, 31, 313-330.

Erler, L., \& Finkbeiner, C. (2007). A review of reading strategies: Focus on the impact of first language. In A. D. Cohen, \& E. Macaro (Eds.), Language learner strategies: Thirty years of research and practice (pp. 187-206). New York, NY: Oxford University Press.

Fehrenbach, C. R. (1991). Gifted/Average readers do they use the same reading strategies? Gifted Child Quarterly, 35(3), 125-127. 
Grabe, W., \& Stoller, F. L. (2001). Reading for academic purposes: Guidelines for ESL/EFL teacher. In M. Celce-Murcia (Ed.), Teaching English as a second or foreign language (pp. 187203). USA: Heinle \& Heinle.

Green, J. M., \& Oxford, R. L. (1995). A closer look at learning strategies, L2 proficiency and gender. TESOL Quarterly, 29(2), 261-297.

Grenfell, M., \& Harris, V. (2002). Modern languages and learning strategies in theory and practice. London: Routledge.

Grenfell, M., \& Macaro, E. (2007). Claims and critiques. In A. D. Cohen, \& E. Macaro (Eds.), Language learner strategies: Thirty years of research and practice (pp. 9-28). New York: Oxford University Press.

Griffiths, C. (2008). Strategies and good language learners. In C. Griffiths (Ed.), Lessons from good language learners (pp. 83-98). Cambridge: Cambridge University press, UK.

Gürses, M. Ö., Bouvet, E. (2016). Investigating reading comprehension and learning styles in relation to reading strategies in L2. Reading in a Foreign Language, 28(1), 20-42.

Hedge, T. (2008). Teaching and learning in the classroom. Oxford: Oxford University Press.

Jafarpanah, Z., \& Farahian M. (2016). The relationship between learning styles and metacognitive reading strategy of EFL learners. International Research in Education. 4(1), 47-54.

Jie, L. (2006). Language learning styles and learning strategies of tertiary level English learners in China. Regional Language Center Journal, 37(1), 67-90.

Kellerman, E. (1991). Compensatory strategies in second language research: A critique, a revision and some implications for the classroom. In R. Philipson, E. Kellerman, L. Selinker, M. Sharwood Smith, \& M. Swain (Eds.), Foreign/second language pedagogy research. (pp. 142-161). Clevendon: Multilingual Matters, UK.

Kinsella, K. (1995). Understanding and empowering diverse learners. In J. M. Reid (Ed.), Learning styles in the ESL/EFL classroom (pp. 170-194). Boston, Mass: Heinle.

Kirby, J. R. (1988). Style strategy and skill in reading. In Schmeck R. R. (Ed), Learning strategies and learning styles. Springer Science and Business Media, New York.

Kolb, D. A. (1976). Management and learning process. California Management Review, 15(3), 20-31.

Kumaravadivelu, B. (2006). Understanding language teaching: From method to postmethod. Mahwah, N.J: Lawrence Erlbaum Associates.

Lee, K. R. (2007). Strategy awareness-raising for success: Reading strategy instruction in the EFL context (Unpublished Doctoral Dissertation). University of Maryland, College Park, MD.

Lee, K. R., \& Oxford, R. L. (2008). Understanding EFL learners' strategy use and strategy awareness. The Asian EFL Journal, 10(1), 7-32.

Macaro, E. (2010). Second language acquisition: the landscape, the scholarship and the reader. In E. Macaro (Ed.), Continuum companion to second language acquisition (pp. 3-28). London: Continuum International Publishing.

Macaro, E., \& Erler, L. (2008). Raising the achievement of young readers of French through strategy instruction. Applied Linguistics, 29(1), 90-119.

McNamara, D. S. (2004). SERT: Self-explanation reading training. Discourse Processes, 38, 130.

Mohammadi, M., Birjandi, P., \& Maftoon, P. (2015). Learning strategy training and the shift in learners' beliefs about language learning: A reading comprehension context. SAGE Open, 111. 
Mokhtari, K., \& Sheorey, R. (2002). Measuring ESL students reading strategies. Journal of Developmental Education, 25(3), 2-10.

Nam, C., \& Oxford, R. L. (1998). Portrait of a future teacher: Case study of learning styles, strategies, and language disabilities. System, 26, 51-63.

Nel, C. (2008). Learning style and good language learners. In C. Griffiths (Ed.), Lessons from good language learners (pp. 49-60). Cambridge, UK: Cambridge University Press.

Nyikos, M. (2008). Gender and good language learners. In C. Griffiths (Ed.), Lessons from good language learners (pp. 73-82). Cambridge, UK: Cambridge University Press.

O'Malley, J. M., \& Chamot, A. U. (1990). Learning strategies in second language acquisition. Cambridge: Cambridge University Press.

Oxford, R. L. (1990). Language learning strategies: What every teacher should know. Boston: Heinle \& Heinle.

Oxford, R. L. (1995). Patterns of cultural identity. Boston: Heinle \& Heinle.

Oxfrod, R. L. (1993). Style analysis survey (SAS). University of Alabama, Tuscaloona, AL.

Oxford, R. L. (2001). Language learning styles and strategies. In M. Celce-Murcia (Ed.), Teaching English as a second or foreign language (pp. 359-366). Boston: Heinle \& Heinle.

Oxford, R. L. (2003). Language learning styles and strategies: Concepts and relationships. Review of Applied Linguistics in Language Teaching, 41, 271-278.

Pallant, J. (2011). SPSS survival manual: A step by step guide to data analysis using the SPSS program ( $4^{\text {th }} E d$.). Allen \& Unwin, Berkshire.

Palinscar, A. S., \& Brown, A. L. (1984). Reciprocal teaching of comprehension fostering and comprehension monitoring activities. Cognition and Instruction, 12, 117-175.

Reid, J. M. (1987, March). The learning style preferences of ESL students. TESOL Quarterly, 21(1), 87-110.

Reid, J. M. (1998). Understanding learning styles in the second language classroom. Upper Saddle River, NJ: Prentice Hall Regents

Rubin, J. (1975). What the "good language learner" can teach us. TESOL Quarterly, 9(1), 41-51.

Rubin, J., Chamot, A. U., Harris, V., \& Anderson, N. J. (2007). Intervening in the use of strategies. In A. D. Cohen, \& E. Macaro (Eds.), Language learner strategies: Thirty years of research and practice (pp. 141-160). New York, NY: Oxford University Press.

Scarella, R. C., \& Oxford, R. L. (1992). The Tapestry of language learning: The individual in the communicative classroom. Boston: Heinle \& Heinle.

Silverman, D. \& Marvasti, A. (2008). Doing qualitative research, A comprehensive guide. Los Angeles: SAGE Publications

Singhal, M. (2011). Reading proficiency, reading strategies, metacognitive awareness and L2 readers. Reading Matrix: An International Online Journal, 1(1), 1-23.

Su, M.-H., \& Duo, P.-C. (2012). EFL learners' language learning strategy use and perceived selfefficacy. European Journal of Social Sciences, 27(3), 335-345.

Swan, C. K. (2015). Effects of online reading strategies and learning styles on reading comprehension of Malaysian tertiary ESL learners. PhD thesis, University Putra Malaysia.

Tabachnick, B. G., \& Fidell, L. S. (2007). Using multivariate statistics (5 ${ }^{\text {th }}$ Ed.). New York: Allyn and Bacon.

Tsai, Y. -R (2012). Investigating the relationship among cognitive learning styles, motivation and strategy use in reading English as a foreign language. International Journal of Business and Social Sciences, 3(13), 188-197.

Uhrig, K. (2015). Learning styles and strategies for language use in the context of academic reading tasks. System, 50, 21-31. 
Wallace, C. (1992). Reading. In C. N. Candlin, \& H. G. Widdowson (Eds.), Language teaching: A scheme for teacher education. Hong Kong: Oxford University Press.

Wenden, A. L., \& Rubin, J. (. (1987). Learner strategies in language learning. New York: Prentice Hall.

White, H., \& S. Sabarwal (2014). Quasi-experimental design and methods, methodological briefs: Impact evaluation 8, UNICEF Office of Research, Florence.

Williams, M., \& Burden, R. L. (2000). Psychology for language teacher: A social constructivist approach. Cambridge, UK: Cambridge University Press.

Wong, L. L., \& Nunan, D. (2011). The learning style and strategies of effective language learners. System, 39, 144-163.

Young W. L. (2006). The relationship between individual differences, training in second language aural comprehension strategies and performance in year 9 Indonesian language students. Retrieved from http://ro.ecu.edu.au/thesis/105.

Zhang, L. J. (2008). Constructivist pedagogy in strategic reading instruction: Exploring pathways to learner development in the English as a second language. Instr Sci, 36, 89-116.

Zhang, L. J., Gu, P. Y., \& Hu, G. (2008). A Cognitive perspective on Singaporean primary school pupils' use of reading strategies in learning to read. British Journal of Educational Psychology 78, 245-271

\section{Copyrights}

Copyright for this article is retained by the author(s), with first publication rights granted to the Journal.

This is an open-access article distributed under the terms and conditions of the Creative Commons Attribution license (CC BY-NC-ND) (http://creativecommons.org/licenses/by-nc-nd/4.0/). 